\title{
CAMPUR KODE BAHASA LISAN MAHASISWA IAIN BUKITTINGGI
}

\author{
Oleh: \\ Jasmienti \\ IAIN Bukittinggi \\ e-mail: jasmienti@gmail.com
}

\begin{abstract}
Abstrak
Tujuan penelitian ini adalah untuk menjelaskan bentuk campur code dan faktor yang menyebabkan interverensi bahasa lisan di jurusan ekonomi islam IAIN Bukittinggi. Analisis data menggunakan deskriftif analisis dengan secara langsung berdiskusi pada bentuk campur kode dan faktor yang menyebabkan adanya gangguan pada campur koce bahasa lisan. Teknik pengumpulan data pada penelitian ini menggunakan observasi, wawancara. Langkah dalam data analisis adalah data reduksi, mendeskripsikan data, pengelompokan data dan kesimpulan. Hasil menunjukkan bahwa komunikasi antara mahasiswa jurusan ekonomi islam terjadi di kampus IAIN Bukuttinggi menggunakan dua bahasa campur kode. Bahasanya adalah Minang dengan Indonesia, Minang dengan Inggris. Hal penelitian tersebut dilihat dari bentuk campur kode yang mempengaruhi bentuk kata kelompok kata, pengulangan kata dan kalimat.
\end{abstract}

Keywords: Mixed Code, oral language

\section{PENDAHULUAN}

Bahasa adalah sebuah alat komunikasi yang digunakan oleh setiap individu, baik manusia maupun binatang dan makhluk hidup yang lainnya.Bahasa juga merupakan alat komunikasai yang sangat dibutuhkan dan memegang peranan penting sebagai ekspresi jiwa. Tanpa adanya sebuah bahasa maka kita tidak akan bisa berkomunikasi dan menukarkan pikiran kita dengan orang lain. Terutama bagi manusia, bahasa sangat dibutuhkan dalam proses interaksi untuk menukar pikiran maupun saling menyamakan pendapat.Manusia bukan makhluk individu melainkan makhluk sosial 
yang di dalam kesehariannya membutuhkan bahasa sebagai alat komunikasi .Di sini bahasa memegang peranan yang sangat penting yaitu selain untuk alat komunikasi juga sebagai alat untuk bertukar pendapat dan bertransaksi. Tanpa sebuah bahasa maka manusia tak akan mampu untuk berbuat banyak. Jika tidak ada bahasa, kita tidak bisa mengungkapkan kepada orang lain tentang apa yang kita fikirkan.

Dalam dunia pendidikan, peranan bahasa jauh lebih penting lagi karena bahasa berperan sebagai pengantar dalam penyampaian ilmu pengetahuan dari guru atau dosen kepada siswa atau mahasiswa. Penggunaan bahasa yang baik dan gaya serta intonasi yang tepat dapat digugunakan oleh oleh guru atau dosen untuk menyampaikan materi pembelajaran sehingga siswa dan mahasiswa dapat menerimanya secara optimal.

Selain itu, dalam kehidupan di lingkungan sekolah atau kampus, siswa atau mahasiswa berinteraksi menggunakan bahasa Indonesia, bahasa ibu dan bahasa lainnya yang berkembang pada saat itu. Hal ini juga berpengaruh terhadap kualitas interaksi akademis antarmahasiswa dalam menjalani proses pendidikan. Namun, bagaimana pemakaian bahasa Indonesia dewasa ini? "Memprihatinkan," kata Kepala Pusat Bahasa, Dendy Sugono. Ia mengemukakan hal itu dalam berbagai kesempatan. Salah satu contoh yang sering ia kemukakan ialah penggunaan bahasa "gadogado", yaitu pencampur-adukan bahasa Indonesia dengan bahasa asing, terutama Inggris. "Ini menunjukkan tidak ada kepercayaan jati diri bangsa,"keluhnya. Sebagai salah satu bentuk keprihatinan, Zaenal Arifin dan Farid Hadi menyusun buku berjudul 1001 Kesalahan Berbahasa. Kesalahan tersebut memang benar-benar berjumlah 1001, suatu jumlah yang banyak.

Problematika di atas juga terjadi di IAIN Bukittinggi. IAIN Bukittinggi saat ini memiliki mahasiswa dari berbagai macam etnis, seperti Mandailing, Tapanuli, Aceh, Jawa dan Minangkabau, serta dari berbagai subetnis Minangkabau seperti Pariaman, Solok, Bukittinggi, Pasaman, Payakumbuh dan Pesisir 
Selatan. Fenomena tersebut berpengaruh terhadap penggunaaan bahasa mahasiswa IAIN Bukittinggi.

Hal ini dapat dilihat pada penggunaan bahasa mahasiswa yang bercampurcampur. Faktanya ditemukan dalam suatu diskusi di kelas yang semula menggunakan bahasa Indonesia kemudian bercampur dengan bahasa Minangkabau, bahasa Inggris, bahasa gaul, dan bahasa lainnya. Begitu juga sebaliknya. Ini dapat dilihat dalam suatu dialog berikut ini;

Si A : "Apakah sesi tanya-jawab bisa kita lanjutkan.?

Si B : " Lanjuikanlah, masih banyak hal menarik lain yang

perlu ditanyakan.!

Si C : “ OK.. silahkan lanjutkan diskusinya.!

Dari contoh dialog di atas dapat dilihat bahwa adanya campur kode. Kata "lanjuikanlah" merupakan kata berbahasa Minangkabau, sedangkan kata "OK" merupakan kata berbahasa Inggris. Masih banyak lagi ditemukan campur kode dalam pembicaraanpembicaraan lainnya baik di dalam perkuliahan maupun di lingkungan kampus IAIN Bukittinggi. Di samping itu, karena perkembangan teknologi dan informasi serta posisi kota Bukittinggi yang di persimpangan, maka penggunaan bahasa gaul semakin berkembang di tengah-tengah mahasiswa IAIN Bukittinggi.

Berdasarkan uraian di atas, penulis tertarik untuk melakukan penelitian dengan judul "Campur Kode Bahasa Lisan Mahasiswa IAIN Bukttimggii.".Tujuan penelitian ini adalah untuk mendeskripsikan bentuk-bentuk campur kode dan faktor- faktor penyebab terjadiya campur kode bahasa lisan mahasiswa IAIN Bukittingi.

\section{PEMBAHASAN}

\section{Kedwibahasaan}

Istilah kedwibahasaan atau dalam bahasa Inggris disebut dengan bilingualism, sangat erat kaitannya dengan kemampuan seseorang dalam menggunakan dua bahasa atau kode bahasa. Berdasarkan kamus linguistik Kridalaksana (2001:31), mengatakan bahwa bilingualism (kedwibahasaan) adalah penggunaan dua bahasa atau lebih oleh seseorang atau oleh suatu masyarakat. Adapun batas kedwibahasaan menurut Wenrich 
(dalam Anwar, 2006:12) adalah peristiwa pemakaian dua bahasa atau lebih secara bergantian oleh seorang penutur atau kebiasaan menggunakan dua dua bahasa dalam berinteraksi dengan orang lain.

Jadi, dapat diambil kesimpulan bahwa kedwibahasaan berhubungan erat dengan pemakaian dua bahasa atau lebih oleh seorang dwibahasawan atau masyarakat dwibahasawan secara bergantian. Pengertian kedwibahasaan adalah pemakaian dua bahasa secara bergantian baik secara produktifmaupun reseptif oleh seorang individu atau oleh masyarakat.

\section{Pengertian Kode}

Kode (code) merupakan lambang atau ungkapan yang dipakai untuk menggambarkan makna tertentu. Bahasa manusia adalah sejenis kode. Bahasa merupakan kode yang dipakai dalam komunikasi manusia dalam melakukan interaksi satu sama lain .(Kridalaksana, 2001:113).

Pemakaian kode berhubungan dengan latar belakang penutur, relasi penutur dengan lawan tutur, dan situasi yang melingkupi

pembicaraan,
Poedjosoedarmo (dalam Rahardi, 2001: 22).Latar belakang penutur bersangkutan dengan tingkat pendidikan dan status sosial. Unsur bahasa yang dipakai oleh kependidikan akan berbeda. Perbedaan itu dapat terletak pada perbendaharaan kata yang dipakainya. Orang yang berpendidikan akan lebih banyak memiliki perbendaharaan kata, baik kata dari bahasa yang digunakan sehari-hari maupun kata dari bahasa asing.

Dari penjelasan di atas dapat disimpulkan bahwa kode merupakan suatu sistem dan variasi bahasa dalam suatu masyarakat dalam berkomunikasi yaitu seperti gaya cerita dan gaya percakapan yang kemudian akan menghasilkan kodekode yang berbeda. Istilah kode dipakai untuk menyebut salah satu varian di dalam hierarki kebahasaan, sehingga selain kode yang mengacu kepada bahasa (seperti bahasa Inggris, Belanda, Jepang, Indonesia, Rusia.

\section{Pengertian Campur Kode}

Campur kode adalah Menurut

Bounvilliain ( 2003:360) "Campur

kode adalah sebuah proses linguistik 
yang menggabungkan materialmaterial dari bahasa kedua kepada bahasa pertama, menambah penandapenanda morfologis dari bahasa dasarkepada elemen-elemen yang telah ada di bahasa pertama".

Sumarsono (Supartinah, 2001: 27), menyebutkan bahwa campur kode terjadi apabila penutur mencampurkan kata variasi bahasa lain ke dalam bahasa yang dipakainya. Dikatakan pula bahwa campur kode merupakan konsekuensi penutur yang menguasai dua bahasa atau lebih.

Dari penjabaran di atas dapat ditarik kesimpulan bahwa campur kode (code mixing) merupakan sebuah kode utama atau kode dasar yang digunakan yang memiliki fungsi dan otonomi.

\section{Bentuk- bentuk Campur Kode}

Dalam penelitian ini akan dibahas pula tentang bentuk-bentuk dari peristiwa campur kode. Adapun bentuk campur kode tersebut adalah berupa kata, frasa, baster, perulangan kata, idiom, serta klausa

a. Kata merupakan unsur terkecil dalam pembentukan kalimat yang sangat penting peranannya dalam tata bahasa, yang dimaksud kata adalah satuan bahasa yang berdiri sendiri, terdiri dari morfem tunggal atau gabungan morfem b. Frasa adalah gabungan dua kata atau lebih yang sifatnya tidak prediktif, gabungan itu dapat rapat dan dapat renggang (Harimurti, 2001: 59).

c. Penyisipan unsur-unsur yang berwujud bentuk baster. Baster merupakan hasil perpaduan dua unsur bahasa yang berbeda membentuk satu makna (Harimurti, 1993:92) Penyisipan unsur-unsur yang berwujud ungkapan atau idiom.

d. Perulangan kata merupakan kata yang terjadi sebagai akibat dari reduplikasi.

e. Idiom merupakan konstruksi dari unsur-unsur yang saling memilih, masing-masing anggota mempunyai makna yang ada hanya karena bersama yang lain atau dengan pengertian lain.

f. Klausa merupakan satuan gramatikal berupa gabungan kata yang sekurang-kurangnya terdiri atas subjek dan predikat, Kridalaksana 1985 (dalam Putrayasa, 2007:11 ). 
5. Faktor-faktor Terjadinya Campur Kode

Suwito (1991:85-87) mengemukakan beberapa factor yang biasanya merupakan penyebab terjadinya campur kode adalah sebagai berikut:

\section{a. Penutur}

Pembicara kadang-kadang sengaja beralih kode terhadap mitra bahasa karena dia mempunyai maksud dan tujuan tertentu. Dipandang dari pribadi pembicara, ada berbagai maksud dan tujuan beralih kode antara lain pembicara ingin mengubah situasi pembicaraan, yakni dari situasi formal yang terikat ruang dan waktu ke situasi non-formal yang tidak terikat ruang dan waktu. Pembicara kadang-kadang melakukan campur kode bahasa satu ke dalam bahasa yang lain karena kebiasaan.

\section{b. Lawan Tutur}

Lawan tutur dapat berupa individu atau kelompok. Dalam masyarakat bilingual, seorang pembicara yang mula-mula menggunakan satu bahasa dapat beralih kode menggunakan bahasa lain dengan lawan tuturnya yang mempunyai latar belakang bahasa daerah yang sama.

c. Hadirnya Penutur

Ketiga
Kehadiran orang ketiga atau orang lain yang tidak berlatar belakang bahasa yang sama dengan bahasa yang sedang digunakan oleh penutur dan lawan tutur dapat menyebabkan peristiwa campur kode. Untuk menetralisasi situasi dan menghormati kehadiran mitra tutur ketiga, biasanya penutur dan mitra tutur mencampur kode, apalagi bila latar belakang kebahasaan mereka berbeda.

d. Pokok Pembicaraan Ttopic)

Dengan menggunakan topik tertentu, suatu interaksi komunikasi dapat berjalan dengan lancar. Campur kode dapat terjadi karena faktor topik.Topik ilmiah disampaikan dalam situasi formal dengan menggunakan ragam formal.Topik nonilmiah disampaikan dalam situasi "bebas", "santai” dengan menggunakan ragam nonformal. Dalam ragam nonformal kadang kadang terjadi "penyisipan" unsur bahasa lain, di samping itu topik pembicaraan non-ilmiah (percakapan sehari-hari) menciptakan pembicaraan yang santai. Pembicaraan yang santai juga dapat menimbulkan campur kode. 
(1) Untuk membangkitkan rasa

humor

Campur kode bahasa sering dimanfaatkan oleh guru, pemimpin rapat atau pelawak untuk membangkitkan rasa humor untuk menyegarkan suasana yang dirasa mulai lesu.

(2) Untuk sekedar bergengsi

Sebagian penutur ada yang mencampur kode bahasa sekedar untuk bergengsi. Hal itu terjadi apabila baik faktor situasi, lawan bicara, topik dan faktor-faktor sosio-situasional yang lain sebenarnya tidak mengharuskan dia untuk mencampur kode..

Analisi Data dan Pembahasan

Analisis Data:

1. Bentuk-bentuk Campur Kode Bahasa Lisan Mahasiswa Fakultas Tarbiyah dan Ilmu Keguruan Semester I IAIN Bukittinggi .

\section{a. Bentuk Kata-kata yang Disisipkan}

\section{Dialog 1}

Ani : "Mau kemana loe Dit?"

Dita: "Gue mau permisi ke belakang" Ani : "Jangan lupa loe beli permen ya"
Dita: "Siiip"

Dialog 2

Loly : “ Ana, aku mau pergi

breakfeast ke kafe"

Kamu mau ikut?"

Ana : "Terima kasih, Loly"

Loly : “Why?. Apa kamu sudah

makan?"

Ana : "Aku tidak lapar, Ly"

\section{Diaolg 3}

Amanda : "Maaf Bu, boleh saya bertanya Buk?"

Ibu Dosen: "Silahkan Amanda"

Amanda : "Saya ndak paham

dengan diksi Buk"

Ibu Dosen: “ Diksi itu adalah pilihan

kata dalam komunikasi baik lisan

maupun tulisan".

Amanda : "Seperti penggunaan kata mati, meninggal, dan mampus yo

Buk?".

Ibuk Dosen: "Betul Amanda”.

Dari dialog 1,2, dan 3 terdapat campur kode dalam bentuk kata. Dalam dialog 1 ditemukan pencampuran kata dalam bahasa gaul yaitu kata loe dan gue. Dialog 2 terdapat pencamuran kata dalam bahasa Inggris yaitu kata: breakfast dan why. Sedangkan dalam dialog 3 
terdapat pencapuran kata dalam

bahasa Minang yaitu kata ndak dan yo

b.

\section{Disisipkan}

\section{Dialog 1}

Ibu Dosen: "Apakah ada hubungan kalimat tiga dengan kalimat empat tadi, Rika?"

Riki : "Ada, Buk”

Ibu Dosen: " Apa hubungannya, Rika?"

Rika : "Enek awak, Buk"

Ibu Dosen: " Kamu ada-ada saja, Rika"

\section{Dialog 2}

Rio : “ Bisakah saya membantu menjawab pertanyaan Dini, Tika?"

Tika : "Silahkan, Rio!"

Rio : "Paragraf adalah kumpulan dari beberapa kalimat yang saling berhubungan".

Tika : " Bagaimana jawaban dari Rio tadi, Dini?"

Apakah sudah bisa

dipahami?"

Dini : "Terima kasih Rio, jawabannya very good Tika"

Kuntum : "Ooooo, begitu ya"

Dialog 3
Dodi : "Siapa yang belum hadir hari ini, Lina?"

Lina : "Siti, Dodi"

Dodi : "Kemana dia, Lina?"

Lina : "Lagi, di perpustakaan, Dodi”

Dodi : “Tolong di SMS ya, Lina?”

Lina : "Ogah Bro, pulsaku kosong"

Dari dialog 1,2, dan 3 terdapat campur kode dalam bentuk frase. Dalam dialog 1 ditemukan pencampuran frase dalam bahasa Minang yaitu enek awak. Dialog 2 terdapat pencamuran kata dalam bahasa Inggris yaitu kata: very good. Sedangkan dalam dialog 3 terdapat pencapuran frasedalam bahasa gaul yaitu kata $O g a h$ bro

\section{c. Bentuk Perulangan Kata yang Disisipkan}

\section{Dialog 1}

Rika : "Kamu kok nggak ngertingerti aja dari tadi, Dev?"

Devi :" Sudah..., yang belum aku pahami contoh penulisan foote note"

Rika: "Makanya kamu perhatikan penjelasan saya tadi" Devi : "Beres, Ka"

“ Aku bener-bener serius sekarang"

Vol.3 No. 2 Juli- Desember 2018/ 188 
Rika : "Begitu dong, Dev"

\section{Dialog 2}

Didi : "Kamu pernah callingcallingan sama Dewi, Don?'

Doni : “ Tidak pernah, dianya sombong sekali”

Didi : " Dewi baik kok, kamunya saja yang angkuh"

Doni :" Aku baik kok, tampangnya saja yang angkuh"

\section{Dialog 3}

Siti:" Saya tidak jadi pergi ke perpustakaan, Gina"

Gina :" Kenapa, Siti?"

Siti :" Tidak tahu, badan saya terasa panek-panek"

Gina:"Kalau begitu, saya sendiri saja yang ke perpustakaan?'

Dari dialog 1,2, dan 3 adalah bentuk campur kode dalam bentuk perulangan kata. Dialog 1 terdapat campur kode kata ulang dalam bahasa gaul yaitu: kata ulang ngertingerti. Dialog 2 terdapat campur kode dalam dalam bentuk kata ulang dalam bahasa Inggris yaitu callingcallingan. Sedangkan pada dialog 3 terdapat pencampuran kata ulang dalam bahasa Minang yaitu panekpanek.

\section{d. Bentuk Klausa yang Disisipkan}

\section{Dialog 1}

Faya : " Tolong ambilkan buku itu, Put"

“ Tempatnya tinggi sekali, help me please!

Putri : "OK, Faya”

" Nih.. bukunya, masih ada yang lain?"

Faya : " Tidak, thank you very much, Putri"

\section{Dialog 2}

Yunita : “ Nin, gimana nich makalahnya" “ Udah loe kerjain apa belom?"

Nindi : "Sudah, ada di dalam tas"

Yunita : "Terima kasih ya, Nin"

“ Berkat kamu aku tidak jadi diskor dosen nanti”

Nindi : "Tidak apa-apa"

\section{Dialog 3}

Kardi : “ Buk, bara kali lai pertemuan awak, Buk?"

Dosen : " Kalau tidak salah pertemuan kita tinggal dua kali lagi?

“ Kenapa ditanya, Kardi?”

Kardi : "Awak kapai liburan lai, Buk? 
Dosen: "Oooooo"

Dari dialog 1, 2, dan 3 adalah campur kode berbentuk klausa. Dialog 1terdapat campur kode berbentuk klausa dalam bahasa Inggris, yaitu: klausa "help me, please" dan klausa "thank you very much" Dialog 2 terdapat campur kode dalam bentuk klausa berbahasa gaul yaitu Nin, gimana nich makalahnya", dan " Udah loe kerjain apa belom?". Sedangkan dialog 3 terdapat campur kode berbentuk klausa dalam bahasa Minang yaitu Buk, bara kali lai pertemuan awak, Buk?" dan Awak kapai liburan lai, Buk?

\section{Faktor Penyebab Terjadinya} Campur Kode Bahasa Lisan Mahasiswa Fakultas Tarbiyah dan Ilmu Keguruan Semester I IAIN

\section{Bukittinggi}

a.. Faktor Penutur (1) faktor keinginan penutur untuk bergengsi (2) faktor keinginan penutur untuk menghormati atau menghargai lawan bicara, atau orang yang dijadikan sasaran pembicaraan, (3) factor keinginan penutur untuk menyanjung lawan bicara atau orang yang dijadikan sasaran pembicaraan

\section{b. Topik Pembicaraan,}

Campur kode terjadi karena.factor topic pembicaraan yang berbeda-beda dan kesederhanaan struktur bahasa lain. Situasi kebahasaan seperti ini yang cendrung ringkas, padat, praktis, dan tidak menyimpang dari kaidah maupun arti dari bahasa aslinya. Terjadinya peristiwa campur kode dalam percakapan informal maupun formal diakibatkan oleh kedwibahasaan yang dimiliki lawan tutur dan situasi yang mendukung penggunaannya. Campur kode merupakan peristiwa yang sulit dihindarkan penutur dwibahasawan karena selalu terdapat kecendrungan dalam diri dwibahasawan untuk memasukkan unsur suatu bahasa ke dalam bahasa lain yang dikuasainya.

\section{c. . Faktor Waktu}

Waktu dan tempat tertentu yang mampu menghadirkan suasana santai dan tidak formal biasanya berpeluang besar untuk terjadinya peristiwa campur kode.

\section{PEMBAHASAN HASIL}

Hasil penelitian ini secara langsung diarahkan pada temuan-temuan penelitian sebagaimana yang digariskan pada dua butir masalah penelitian.

Vol.3 No. 2 Juli- Desember 2018/ 190 
1. Bentuk-bentuk campur kode bahasa lisan mahasiswa IAIN Bukittingi.

Temuan pertama yaitu terdapatnya penyisipan kata yang digunakan mahasiswa dalam percakapan di kanpus maupun di dalam perkuliahan. Bentuk kata yang disipkan tersebut berasal dari bahasa Minang, bahasa Ingris, dan bahasa gaul.

Temuan kedua yaitu Bentuk Frase yang Disisipkan berasal dari frase bahasa Minanng, gaul, dan bahasa Inggris.

Temuan ketiga bentuk Perulangan Kata yang Disisipkan juga berasal dari bahasa Inggris, bahasa gaul, dan bahasa Inggris.

Temuan keempat bentuk Klausa yang Disisipkan adalah bahasa Minang, bahasa gaul, dan bahasa Inggris

Berdasakan keempat temuan di atas bahwa bentuk campur kode yang terdapat pada bahasa lisan mahasiswa IAIN pada Fakultas Tarbiyah dan Ilmu Kependidikan adalah bahasa gaul, bahasa Inggris, dan bahasa Minang.

2. Faktor Penyebab Terjadinya Campur Kode Lisan Mahasiswa Fakultas Tarbiyah dan Ilmu
Keguruan Semester II IAIN Bukittinggi

Bertdasarkan hasil temuan bahwa factor penyebab terjadinya campur kode adalah factor penutur, topic pembicaraan dan factor wakru.

Bentuk dan ragam bahasa yang memuncukan campur kode harus dapat diminimalkan penggunaannya dalam komunikasi, walaupun dalam situasi formal maupun informal karena pemakaian kosa kata bahasa daerah ataupun bahasa asing tersebut dapat dikatakan sebagai bentuk penyimpangan dalam penggunaan bahasa dari norma-norma yang ada. Wujud atau bentuk yang memunculkan campur kode terutama yang berasal dari bahasa Minang diperlukan pemahaman lebih mendalam lagi untuk menghindari adanya bentuk penyimpangan dan diperlukan kajian yang lebih spesifik dan komprehensif terhadap faktorfaktor penyebab campur kode.

DAFTAR PUSTAKA

Arikunto, Suharsimi. 2002. Prosedur Penelitian Suatu Pendekatan Pragtik. Yogyakarta: Rineka Cipta. 
Bloomfield, Leonard. 1995.

Language-Bahasa. Jakarta: PT

Gramedia PustakaUtama.

Bounvillain, Nancy. 2003.4th edition,

Language, Culture and

Communication,

The

MeaningMessages. New Jersey:

Prentice Hall.

Chaer, Abdul dan leony, Agustina.

1995. Pengantar Awal liguistik.

Jakarta. Rieneka Cipta.

Chaer, Abdul. 1994. LinguistikUmum, Jakarta: PT. Rineka Cipta.

Crystal, David. 1994. An Encyclopedic Dictionary of Language and Languages.

London:Penguin Group

Fishman, J.A. 1977. Sosiolinguistik

Suatu Pengantar Ringkasan.

Terjemahan. Jakarta : Pusat

Pembinaan dan Pengembangan

Bahasa Departemen Pendidikan

dan Kebudayaan. I

Fishman, Joshua R. 1972. The

Sociology of Language.

Rowley: Newbuty House

Kridalaksana, Harimukti. 2001.

Kamus Linguistik. Jakarta:

Gramedia.
Mahsun.

2007.

MetodePenelitianBahasa. Jakarta: Raja Grafindo Persada.

Nababan, P.W.J. 1983. Sosioliguistik Suatu Pengajaran. Jakarta. Gramedia.

Rahardi, Kunjana. 2001. Sosioliguitik Kode dan Alih Kode.Yogyakarta: pustaka Pelajar.

Subyakto. 1992. Metode dan Teknik Analisis Bahasa. Yogyakarta: Duta Wacana University Press.

Sudaryanto.1988. Metode Linguistik Bagian Pertama. Yobyakarta: Gajah Mada University Press.

Sujana, Nana dan Ibrahim. 2001. Penelitian dan Penilaian Pendidikan. Bandung: Sumur Baru Algensindo

Suwito.1985. Sosiolinguistik Pengantar Awal. Solo: Henry Offset.

Verhaar. JMW. 2004. Asas-Asas Linguistik Umum. Yogyakarta: Gajah Mada University Press.

Wardhaugh, $\quad$ Ronald. 1986. AnIntroduction to Sociolinguistics. Oxford: Basil Blackwell. 